Article

\title{
Effect of Powdered Activated Carbon to Reduce Fouling in Membrane Bioreactors: A Sustainable Solution. Case Study
}

\author{
Vincenzo Torretta $^{1, *}$, Giordano Urbini ${ }^{1}$, Massimo Raboni ${ }^{1}$, Sabrina Copelli ${ }^{1}$, Paolo Viotti ${ }^{2}$, \\ Antonella Luciano ${ }^{2}$ and Giuseppe Mancini $^{3}$
}

1 Department of Science and High Technology, Insubria University, Via G.B. Vico 46, Varese I-21100, Italy; E-Mails : giordano.urbini@uninsubria.it (G.U.); massimo.raboni@uninsubria.it (M.R.); sabrina.copelli@uninsubria.it (S.C.)

2 Department of Civil, Building and Environmental Engineering, Sapienza University of Rome, Via Eudossiana 18, Rome I-00184, Italy; E-Mails: paolo.viotti@uniroma1.it (P.V.); antonella.luciano@uniroma1.it (A.L.)

3 Department of Industrial and Mechanical Engineering, University of Catania, Viale Andrea Doria 6, Catania I-95125, Italy; E-Mail: gmancini@dica.unict.it

* Author to whom correspondence should be addressed; E-Mail: vincenzo.torretta@uninsubria.it; Tel.: +39-0332-218-782; Fax: +39-0332-218-779.

Received: 28 January 2013; in revised form: 26 March 2013 / Accepted: 27 March 2013 /

Published: 3 April 2013

\begin{abstract}
Membrane Bio Reactors (MBRs) are mainly used for industrial wastewaters applications where their costs can be more easily afforded. High costs are basically due to energy consumption and membrane cleaning or replacement. Membrane fouling is responsible for reducing treated water production and increasing maintenance as well as operation costs. According to previous researches, the addition of Powdered Activated Carbon (PAC) in high dosages could reduce membrane fouling; but such concentrations are economically unsustainable for operative conditions. A MBR pilot plant, fed by mixed liquor of a full-scale activated sludge process from a municipal wastewater treatment plant, was operated dosing low PAC concentrations $\left(0,2,5,10\right.$ and $20 \mathrm{mg} \cdot \mathrm{L}^{-1}$, respectively). Experiments were also carried out at two different temperatures corresponding to summer and winter conditions. Results indicated that PAC addition was effective at the low dosages ( 2 and $5 \mathrm{mg} \cdot \mathrm{L}^{-1}$ ) by reducing the permeate flux loss (from 16 up to $27 \%$, respectively) while higher PAC concentrations turns out in a useless cost increase.
\end{abstract}


Keywords: membrane bioreactor; powdered activated carbon; municipal wastewater; fouling; pilot plant

\section{Introduction}

Although membrane bioreactor (MBR) applications allow several advantages (e.g., higher performances, lower space requirements, lower sludge production) with respect to conventional activated sludge [1,2]. Their extensive application to urban wastewater treatment is still restrained due to the capital as well as the operation and maintenance (O\&M) costs (e.g., energy and membrane replacement). Energy consumptions span from $0.50-0.80 \mathrm{kWh} \cdot \mathrm{m}^{-3}$ for flat sheet membrane to around $0.15 \mathrm{kWh} \cdot \mathrm{m}^{-3}$ for tubular membranes. Membranes and system configurations costs (approximately $43-47 €$ Equivalent inhabitant ${ }^{-1}$ for flat sheet and $42-43 €$ Equivalent inhabitant ${ }^{-1}$ for tubular) decreased over the past 10 years as a result of their increased diffusion, improvements in process design, more sophisticated control of the operating parameters and backwashing operation strategy. Also their life time has been expanded [3]. One important issue, still affecting the O\&M cost, is the membrane replacement due to excessive fouling. Fouling causes significant increase in hydraulic head loss, manifested as permeate flux decline or transmembrane pressure (TMP) increase, depending on whether the treatment is operated under constant-TMP or constant-flux conditions. Therefore, fouling brings to an increase of MBR systems energy demand. Frequent membrane cleaning is therefore required, increasing significantly the operating costs as a result of cleaning agents and production downtime. More frequent membrane replacement is also expected. Many authors [4-7] have shown that membrane fouling (and deriving energy costs increase) remains the most adverse barrier to the MBR implementation both in urban and industrial wastewater treatment sectors, remaining one of the most challenging issues to face further MBR development.

Many factors can influence membrane fouling [4]. The main factors are: biomass characteristics; extracellular polymers; inorganic precipitates or scalants; colloids; operative conditions $[8,9]$.

Several researches [5,10-12] have shown that the addition of Powdered Activated Carbon (PAC) to sludge contributes in reducing membrane fouling. However, most of these contributions regard relatively narrow PAC concentration ranges and mainly industrial wastewater applications, as shown in Table 1. Moreover, economic issue is not fully investigated even if some authors indicate it as the most important criteria to assess MBR applicability.

Remy et al. [5] proposed a very comprehensive resume of the main research contributions on this issue and reported that the addition of low PAC concentrations can increase the permeate flux of about $10 \%$ by improving the membrane filtration performance.

Considering other experiences, Pirbazari et al. [10] observed that a PAC concentration of $10 \mathrm{~g} \cdot \mathrm{L}^{-1}$, in a cross-flow ultrafiltration-MBR treating high strength landfill leachate, resulted in less fouling. This effect was explained by the deposition of a dynamic and permeable PAC layer on the membrane surface, protecting it from the deposition of foulants. 
Table 1. Example of some results from previous researches.

\begin{tabular}{|c|c|c|c|c|}
\hline Author & Wastewater & PAC type & $\begin{array}{l}\text { Dosage } \\
\left(g \cdot \mathbf{L}^{-1}\right)\end{array}$ & Flux reduction or other benefit \\
\hline$[13]$ & $\begin{array}{l}\text { High strength wastewater from } \\
\text { an alcohol distillery }\end{array}$ & \multirow{2}{*}{$\begin{array}{c}\text { Commercial } \\
\text { (steam activated } \\
\text { wood charcoal) }\end{array}$} & 2.0 & \multirow{2}{*}{$\begin{array}{l}\text { PAC addition allowed continuous operation } \\
\text { at a constant flux for } 20 \mathrm{~d} \text { without filter } \\
\text { change or cleaning. This duration was } \\
\text { shorter }(8 \mathrm{~d}) \text { without PAC addition. }\end{array}$} \\
\hline$[13]$ & $\begin{array}{l}\text { Sugarcane molasses based } \\
\text { distillery wastewater } \\
\text { (spentwash) }\end{array}$ & & 2.0 & \\
\hline$[14]$ & $\begin{array}{l}\text { Municipal secondary effluent } \\
\text { from a traditional active sludge } \\
\text { process }\end{array}$ & Generic & 0.75 & $\begin{array}{l}\text { Sustainable operating time was extended by } \\
\text { up to } 2 \text { times through PAC addition, } \\
\text { reducing membrane fouling. }\end{array}$ \\
\hline$[15]$ & Synthetic wastewater & Generic & 1.20 & $\begin{array}{l}\text { Effective flux reduction control was } \\
\text { accomplished by adding PAC. } \\
\text { The near-critical flux for the PAC system } \\
\text { could be raised by about } 32 \% \text {. Operating } \\
\text { intervals could be extended about } 1.8 \text { times. }\end{array}$ \\
\hline$[16]$ & Various & $\begin{array}{c}\text { SA Super } \\
\text { Picahydro LP27 } \\
\text { (Norit) }\end{array}$ & 5.0 & Different and interesting results \\
\hline
\end{tabular}

Ying and Ping [11] reported a similar effect when dosing 0.75 and $1.5 \mathrm{~g} \cdot \mathrm{PAC} \cdot \mathrm{L}^{-1}$. The scouring effect that permits the removal of deposited foulants from the membrane surface was also reported by Park et al. [17] with a PAC concentration of $5 \mathrm{~g} \cdot \mathrm{L}^{-1}$ applied in anaerobic MBRs.

Fang et al. [18] and [19] indicated the adsorption of foulants to the PAC particles as the responsible mechanism (2-5 $\mathrm{g} \cdot \mathrm{PAC} \cdot \mathrm{L}^{-1}$ activated sludge) of fouling reduction, but also observed as frequent refreshing of the PACs was necessary because foulants saturate them, while operation at an infinite solid retention time (SRT) did not exhibit a positive effect on filterability. Fouling reduction was explained by a stronger sludge floc structure [20,21].

Remy et al. [5-7] analyzed the course of the TMP during the critical permeate flux determination. No PAC sludge exhibited a higher TMP than sludge with PAC. It was also shown as PAC-added sludge had a $19 \%$ higher critical flux. PAC addition shows an increase in the biggest particle size but a reduction in the mean particle dimension $(-30 \%)$. In the sludge without PAC the extra shear also caused an increase of supernatant composed of Chemical Oxygen Demand (COD), polysaccharides and multivalent cations $\left(\mathrm{Ca}^{2+}\right.$ and $\left.\mathrm{Mg}^{2+}\right)$. The release of the polysaccharides could explain the higher fouling [5].

Fan et al. [22] considered the effects of sludge characteristics on critical flux using a submerged MBR pilot plant applied to urban wastewater working at different operative conditions. Similar results were obtained by Wang et al. [23] in a submerged membrane bioreactor under sub-critical flux operation.

The need to reduce membrane fouling appears to be a critical technical challenge affecting MBR process performance and economics.

The main goal of the present research was to analyze effects of PAC addition in a pilot scale MBR plant, in order to evaluate the most suitable concentrations able to guarantee an improvement of the treatment yield in terms of permeate flux loss. In particular, the results are discussed in order to 
determine the minimum concentrations reducing the negative effects of fouling, also considering temperature effect due to seasonal change. The approach aims to find sustainable solutions to remove micropollutants from wastewater, reducing the charge on environment and the risks for human health [24].

\section{Materials and Methods}

All membrane bioreactor experiments were carried out in a pilot plant fed with mixed liquor coming from the activated sludge tank of a full scale wastewater treatment plant (WWTP).

The WWTP attends to a very large basin in an area with very high density of population and industrial activities. Specifically, the municipal to industrial wastewater ratio is about the 70/30. As a consequence, a significant presence of micropollutants and PAHs characterizes the influent $[25,26]$. The averaged inflow/outflow data in the months of January and July are reported in Table 2.

Table 2. Wastewater treatment plant (WWTP) data during experimental activities (inflow, inlet and outlet quality parameters).

\begin{tabular}{lrrrr}
\hline \multirow{2}{*}{ Parameter } & \multicolumn{2}{c}{ January } & \multicolumn{2}{c}{ July } \\
\cline { 2 - 5 } & \multicolumn{1}{c}{ inlet } & outlet & \multicolumn{1}{c}{ inlet } & outlet \\
\hline Inflow $\left(\mathrm{m}^{3} \cdot \mathrm{d}^{-1}\right)$ & 30,000 & - & 28,000 & - \\
$\mathrm{COD}\left(\mathrm{mg} \cdot \mathrm{L}^{-1}\right)$ & 105 & 21 & 153 & 17 \\
$\mathrm{BOD}_{5}\left(\mathrm{mg} \cdot \mathrm{L}^{-1}\right)$ & 49 & 6.4 & 48 & 4.6 \\
$\mathrm{~N}-\mathrm{NO}_{3}\left(\mathrm{mg} \cdot \mathrm{L}^{-1}\right)$ & 1.9 & 6.7 & 4.9 & 4.9 \\
$\mathrm{~N}-\mathrm{NH}_{4}\left(\mathrm{mg} \cdot \mathrm{L}^{-1}\right)$ & 14.9 & 0.50 & 14.6 & 0.25 \\
$\mathrm{TKN}\left(\mathrm{mg} \cdot \mathrm{L}^{-1}\right)$ & 17.50 & 1.59 & 19.45 & 1.77 \\
Total phosphorus $\left(\mathrm{mg} \cdot \mathrm{L}^{-1}\right)$ & 2.90 & 0.48 & 3.20 & 0.29 \\
\hline
\end{tabular}

The pilot plant layout is shown in Figure 1. It was located near the full scale activated sludge reactor for minimizing the head loss due to mixed liquor pumping.

Figure 1. Process layout.

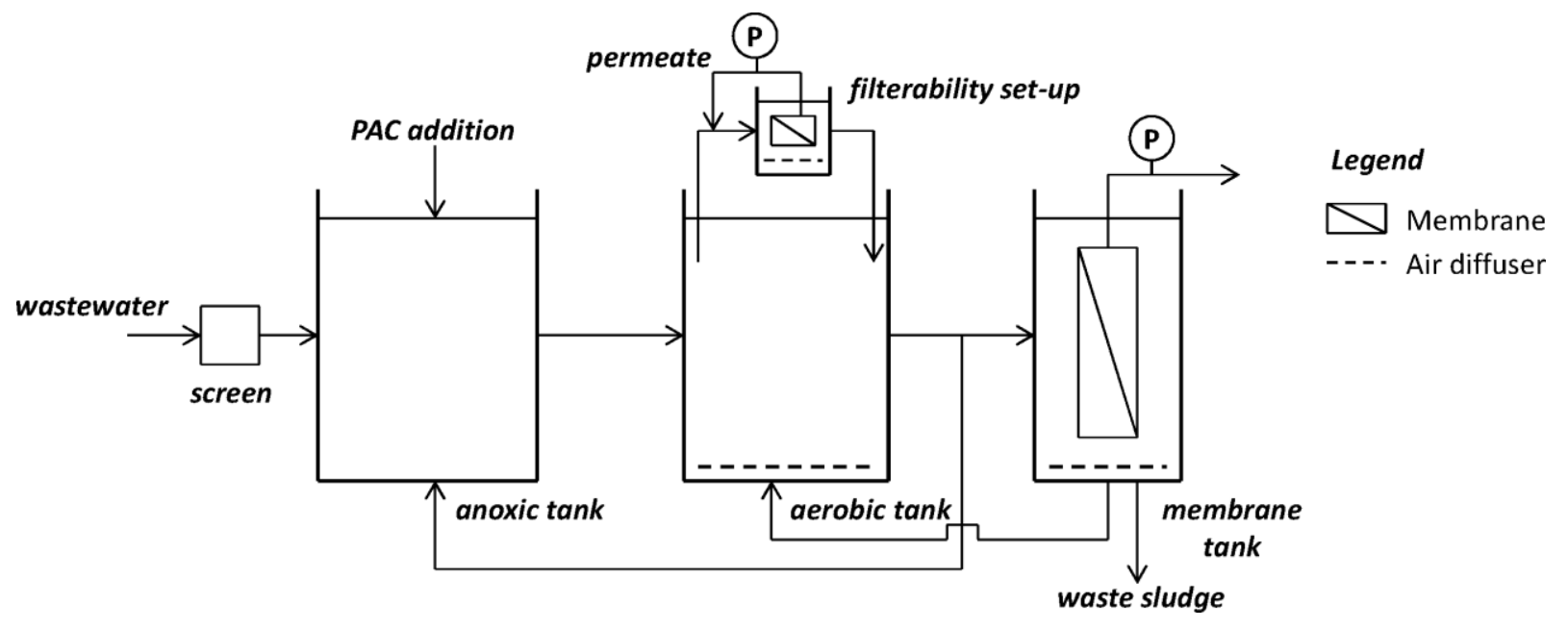

The maximum tank volume was $0.050 \mathrm{~m}^{3}$, with an air diffuser system applied to the bottom of the tank. The MBR was a TMP system characterized by a tubular inorganic membrane. MBR system operating conditions and membrane main characteristics are shown, respectively, in Tables 3 and 4. 
Table 3. Membrane bioreactor (MBR) main characteristics and operating conditions.

\begin{tabular}{lcc}
\hline \multicolumn{1}{c}{ Parameter } & Unit & Value \\
\hline Reactor volume & $\mathrm{L}$ & 50 \\
Hydraulic retention time, HRT & $\mathrm{h}$ & 10 \\
Solid retention time, SRT & $\mathrm{d}$ & 50 \\
Mixed liquor suspended solids, $M L S S$ & $\mathrm{mg} \cdot \mathrm{L}^{-1}$ & 4 \\
Average temperature & ${ }^{\circ} \mathrm{C}$ & 12 (January) and 22 (July) \\
\hline
\end{tabular}

Table 4. Membrane main characteristics.

\begin{tabular}{lcc}
\hline \multicolumn{1}{c}{ Parameter } & Unit & Value \\
\hline Membranes type and module model & - & Tubular inorganic membrane \\
& & porous carbon support (Dow FILMTEC ${ }^{\mathrm{TM}}$ ) \\
Frame support material & - & AISI 304 \\
Internal diameter & $\mathrm{mm}$ & 6 \\
External diameter & $\mathrm{mm}$ & 10 \\
Membrane pores size & $\mu \mathrm{m}$ & 0.05 \\
Trans-membrane pressure, TMP & bar & 0.8 \\
Range of working temperature & ${ }^{\circ} \mathrm{C}$ & $10-40$ \\
Max backwashing TMP & bar & 1.1 \\
Backwashing period & $\mathrm{min}$ & 30 (duration: $30 \mathrm{~s})$ \\
\hline
\end{tabular}

Two sampling campaigns were carried out at different periods (January and July) with the aim of evaluating temperature influence on results. Experiments had the duration of $168 \mathrm{~h}$, and plant operative conditions were kept constant. Tests were carried out both with and without the PAC addition at different concentrations $\left(2,5,10\right.$ and $20 \mathrm{mg} \cdot \mathrm{L}^{-1}$ respectively). PAC was added to water flux through a preparer-batcher. PAC main characteristics and cost are reported in Table 5.

Table 5. Powdered activated carbon (PAC) main characteristics and cost.

\begin{tabular}{lcc}
\hline \multicolumn{1}{c}{ Parameter } & Unit & Value \\
\hline Brunauer-Emmett-Teller (BET) surface area & $\mathrm{m}^{2} \cdot \mathrm{g}^{-1}$ & $600-800$ \\
Iodine number & $\mathrm{mg} \cdot \mathrm{g}^{-1}$ & 760 \\
Humidity & $\%$ & 15.6 \\
Density & $\mathrm{kg} \cdot \mathrm{m}^{-3}$ & 400 \\
Granulometry (refusal on a sieve with a $20 \mu \mathrm{m}$ diameter) & $\%$ & 85 \\
Current cost & $€ \cdot \mathrm{t}^{-1}$ & $1,230-1,550$ \\
\hline
\end{tabular}

Permeate flux $J$ was monitored during the test and used as an indicator of the filtration process performance.

\section{Results and Discussion}

The results, obtained with a high SRT (50 d), are expressed as percentage of the permeate flux with clean membrane, $J_{\text {clean }}$ (see Figures 2 and 3). 
Figure 2. Influence of PAC concentration on permeate flux — winter conditions.

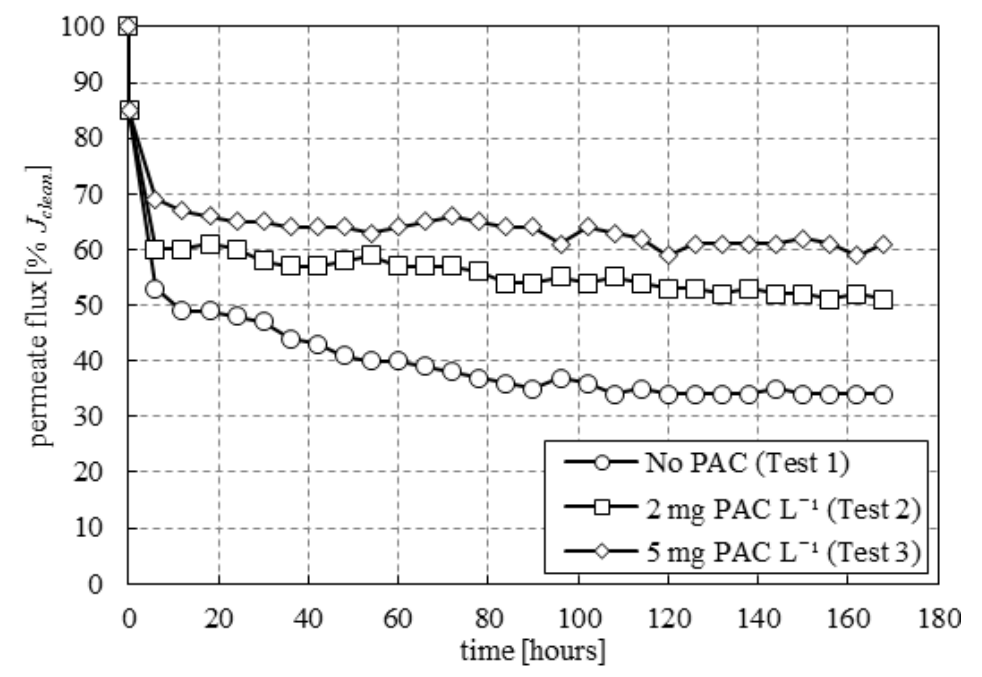

Figure 3. Influence of PAC concentration on permeate flux — summer conditions.

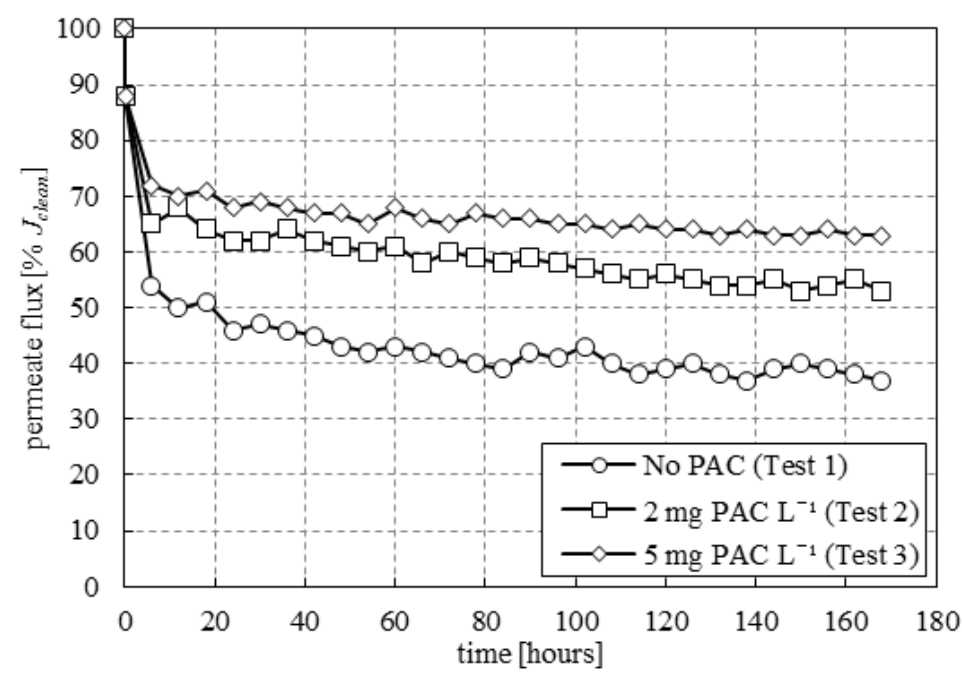

It can be noticed that MBR filtration performance inevitably decreases with filtration time and PAC addition brings to positive immediate effects (within about $6 \mathrm{~h}$ ) in permeate flux loss. Moreover, PAC maintains permeate flux more stable over time.

PAC significantly improves the permeate flux loss both in summer and winter conditions in a similar manner, but the performances related to adding $5 \mathrm{mg} \cdot \mathrm{PAC} \cdot \mathrm{L}^{-1}$ are higher than dosing $2 \mathrm{mg} \cdot \mathrm{PAC} \cdot \mathrm{L}^{-1}$ (about $26-27 \%$ with respect to $16-17 \%$ ).

Starting from the obtained results, a second set of experiments using higher concentrations of PAC (10 and $20 \mathrm{mg} \cdot \mathrm{L}^{-1}$ ) was carried out for a period of $96 \mathrm{~h}$. Results are shown in Figure 4.

Obtained results do not encourage the application of PAC concentration higher than $5 \mathrm{mg} \cdot \mathrm{L}^{-1}$ because no further improvements in terms of permeate flux are achieved. In fact the permeate flux loss is almost the same (after 4 days the measured value is around 62-65\%). 
Figure 4. Influence of high PAC concentration on permeate flux-summer conditions.

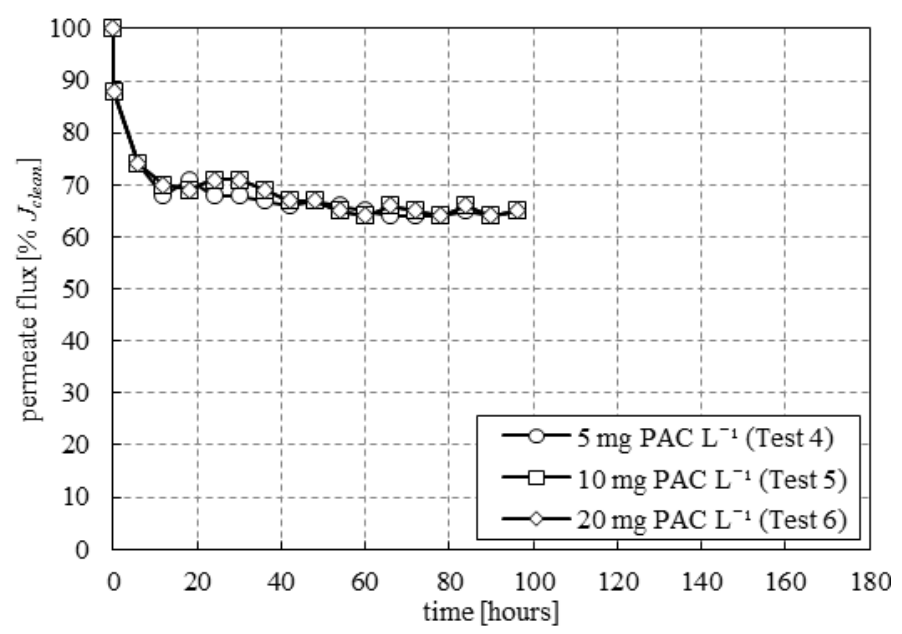

\section{Conclusions}

Results from this research enforce previous experiences reported in technical literature, confirming that PAC addition, in low concentrations, can contribute to reduce the membrane fouling in MBR systems. The enhanced performances have been evaluated through a decrease in the permeate flux loss over time. PAC addition in low dosage $\left(5 \mathrm{mg} \cdot \mathrm{L}^{-1}\right)$ makes possible to halve the permeate flux loss while other tests carried out with higher concentrations did not reveal significant efficiency improvements. Moreover, the temperature influence (considering two series of tests carried out at 12 and $22{ }^{\circ} \mathrm{C}$, respectively) is negligible.

The benefit of PAC addition improves the MBR filtration performances, such as the energy consumption reduction due to mitigation of TMP increase (or flow rate decrease), elongation of cleaning in place as well as physical cleaning intervals.

In conclusion, the solution, considering both material cost and benefits regarding the increased yields, presents a significant level of economic and environmental sustainability for mixed civil and industrial wastewater treatment.

\section{Conflict of Interest}

The authors declare no conflict of interest.

\section{References}

1. Davies, W.J.; Le, M.S.; Health, C.R. Intensified activated sludge process with submerged membrane microfiltration. Water Sci. Technol. 1998, 38, 421-428.

2. Zhou, H.; Smith, D.W. Advanced treatment technologies in water and wastewater treatment. Can. J. Civil Eng. 2001, 28, 49-66.

3. Judd, S. The MBR Book. Principles and Applications of Membrane Bioreactors in Water and Wastewater Treatment; Elsevier: Amsterdam, The Netherlands, 2007.

4. Choi, J.H.; Yong, N.G. Effect of membrane type and material on performance of a submerged membrane bioreactor. Chemosphere 2008, 71, 853-859. 
5. Remy, M.; Van der Marel, P.; Zwjnenburg, A.; Rulkens, W.; Temmink, H. Low dose powdered activated carbon addition at high sludge retention times to reduce fouling in membrane bioreactors. Water Res. 2009, 43, 345-350.

6. Remy, M.; Potier, V.; Temmink, H.; Rulkensb, W. Why low powdered activated carbon addition reduces membrane fouling in MBRs. Water Res. 2010, 44, 861-867.

7. Remy, M.; Temmink, H.; Rulkens, W. Effect of low dosages of powdered activated carbon on membrane bioreactor performance. Water Sci. Technol. 2012, 65, 954-961.

8. Bai, R.B.; Leow, H.F. Microfiltration of activated sludge wastewater-The effect of system operation parameters. Sep. Purif. Technol. 2002, 29, 189-198.

9. Lyko, S.; Wintgens, T.; Al-Halbouni, D.; Baumgarten, S.; Tacke, D.; Drensia, K.; Janot, A.; Dott, W.; Pinnekamp, J.; Melin, T. Long-term monitoring of a full scale municipal membrane bioreactor-Characterization of foulant and operational performance. J. Membrane Sci. 2008, 317, 78-87.

10. Pirbazari, M.; Ravindram, V.; Badriyha, B.N.; Kim, S.H. Hybrid membrane filtration process for leachate treatment. Water Res. 1996, 30, 2691-2706.

11. Ying, Z;; Ping, G. Effect of powdered activated carbon dosage on retarding membrane fouling in MBR. Sep. Purif. Technol. 2006, 52, 154-160.

12. Satyawali, Y.; Balakrishnan, M. Effect of PAC addition on sludge properties in an MBR treating high strength wastewater. Water Res. 2009, 43, 1577-1588.

13. Satyawali, Y.; Balakrishnan, M. Performance enhancement with powdered activated carbon (PAC) addition in a membrane bioreactor (MBR) treating distillery effluent. J. Hazard Mater. 2009, 170, 457-465.

14. Lin, H.; Wang, F.; Ding, L.; Hong, H.; Chen, J.; Lu, X. Enhanced performance of a submerged membrane bioreactor with powdered activated carbon addition for municipal secondary effluent treatment. J. Hazard. Mater. 2011, 192, 1509-1514.

15. Li, X.; Gao, F.; Hua, Z.; Du, G.; Chen, J. Treatment of synthetic wastewater by a novel MBR with granular sludge developed for controlling membrane fouling. Sep. Purif. Technol. 2005, 46, 19-25.

16. Iversen, V.; Mehrez, R.; Horng, R.Y.; Chen, C.H.; Meng, F.; Drews, A.; Lesjean, B.; Ernst, M.; Jekel, M.; Kraume, M. Fouling mitigation through flocculants and adsorbents attion in membrane bioreactors: Comparing lab and pilot studies. J. Membrane Sci. 2009, 345, 21-30.

17. Park, H.; Choo, K.-H.; Lee, C.-H. Flux enhancement with powdered activated carbon addition in the membrane anaerobic bioreactor. Sep. Sci. Technol. 1999, 34, 2781-2792.

18. Fang, H.H.P.; Shi, X.; Zhang, T. Effect of activated carbon on fouling of activated sludge filtration. Desalination 2006, 189, 193-199.

19. Ng, C.A.; Sun, D.; Fane, A.G. Operation of membrane bioreactor with powdered activated carbon addition. Sep. Sci. Technol. 2008, 41, 1447-1466.

20. Hu, Y.; Stuckey, D.C. Activated carbon addition to a submerged anaerobic membrane bioreactor: effect on performance, transmembrane pressure, and flux. J. Environ. Eng. 2007, 133, 73-80.

21. Li, Y.Z.; He, Y.L.; Liu, Y.H.; Yang, S.C.; Zhang, G.J. Comparison of the filtration characteristics between biological powdered activated carbon sludge and activated sludge in submerged membrane bioreactors. Desalination 2005, 174, 305-314. 
22. Fan, F.; Zhou, H.; Husain, H. Identification of wastewater sludge characteristics to predict critical flux for membrane bioreactor processes. Water Res. 2006, 40, 205-212.

23. Wang, Z.; Wu, Z.; Yin, X.; Tian, L. Membrane fouling in a submerged membrane bioreactor (MBR) under sub-critical flux operation: Membrane foulant and gel layer characterization. J. Membrane Sci. 2008, 325, 238-244.

24. Di Mauro, C.; Bouchon, S.; Torretta, V. Industrial risk in the Lombardy Region (Italy): What people perceive and what are the gaps to improve the risk communication and the partecipatory processes. Chem. Eng. Trans. 2012, 26, 297-302.

25. Torretta, V. PAHs in wastewater: Removal efficiency in a conventional wastewater treatment plant and comparison with model predictions. Environ. Technol. 2012, 33, 851-855.

26. Torretta, V.; Katsoyiannis, A. Occurrence of polycyclic aromatic hydrocarbons in sludges from different stages of a wastewater treatment plant in Italy. Environ. Technol. 2012, doi: 10.1080/09593330.2012.722693.

(C) 2013 by the authors; licensee MDPI, Basel, Switzerland. This article is an open access article distributed under the terms and conditions of the Creative Commons Attribution license (http://creativecommons.org/licenses/by/3.0/). 